\section{Estimating Yields of Gambel Oak from Foliage Cover and Basal Area ${ }^{1}$}

\section{SELAR S. HUTCHINGS AND LAMAR R. MASON}

Principal Plant Ecologist, Intermountain Forest and Range Experiment Station, Forest Service, USDA, Ogden, Utah, and Range Conseruationist, Soil Conservation Service, USDA, Salt Lake City, Utah.

\section{Highlight}

This study of Gambel oak (Quercus gambelii Nutt.) shows that annual yields of foliage and twigs can best be estimated from measurements of foliage and basal area. Equations for predicting yield of oakbrush foliage are given for various range sites and range condition classes. Foliage yields and yield equations are different for each site and each condition class. Yield tables illustrate the relation of foliage production to foliage area and basal area.

Yields of all vegetation, including large brush species such as Gambel oak (Quercus gambelii Nutt.), are necessary to fully evaluate native range-

${ }^{1}$ Received August 19, 1969; accepted for publication November $12,1969$. land site potential. Total annual shrub yield estimation is time consuming and requires constant training and checking to insure accuracy. A yield prediction formula, utilizing one or two simple measurements, can save time and increase accuracy. Data for this study, collected in 1964, 1965, and 1966 indicate that reliable yield estimates, computed from measurements of foliage area, are more accurate when measurements of basal stem area are included. Such estimates can be made rapidly and without personal bias.

\section{Methods}

Study areas were located on five different Utah range sites: high mountain loam; mountain loam; mountain shallow loam; mountain stony loam; and upland loam. All study areas were at elevations between 5,500 and 8,000 feet. Average annual precipitation ranged between 14 and 26 inches. Study locations, concentrated in Iron, Sanpete, and Wasatch Counties, represented the southern, central, and northern portions of this species' distribution in Utah. No samples were taken near the boundaries of the oakbrush zone.

In 1964, transects containing five to 10 square plots, $1 / 200$ acre in size, were used to sample dense stands of oakbrush. The same number of $1 / 100$-acre plots was used to sample scattered stands. In 1965 and 1966, data were taken 
on $1 / 100$-acre belt transects, 4.356 feet wide and one hundred feet long.

On each plot, oakbrush foliage was separated into small clumps or segments that had unbroken foliage canopies. Foliage width, length, and height of each clump were measured to the nearest 0.5 foot. Scattered patches of oakbrush foliage with broken canopies were measured separately, or patches of foliage were pulled together to eliminate crown openings. Average stem height in each clump was measured to the nearcst 0.5 foot, and avcrage stcm diameter at ground level, to the nearest 0.1 inch. The number of stems in each clump also was recorded. Foliage on a stem over 6 feet high was recorded separately. A single branch or small area of foliage was selected as a standard for estimating or counting weight units on each clump. When all measurements were recorded, foliage, acorns, and annual twig growth were clippcd from the wcight unit, air-dricd 3 or 4 weeks, and weighed. Total air-dry weight was computed by multiplying sample unit weight by the number of weight units in each oakbrush clump. Foliage area and basal stem area were computed as follows: foliage area $=$ width $\times$ length; basal area $=$ average stem diameter squared $\times$ number of stems.

\section{Range Sites and Condition Classes}

Oak production was sampled within three climatic zones. The terms "high mountain," "mountain," and "upland" refer to specific climatic characteristics associated with elevation and topography.

\section{High Mountain Zone}

Climate is cool and humid; winters are cold and snowy, summers are cool; average annual precipitation ranges between 22 and 26 inches. Areas sampled ranged from 7,000 to 9,500 feet elevation. Soils are similar to those in the mountain loam range site, except that they contain more organic material, are better developed, and have a moistureholding capacity of 8 to 9 inches in a 6 -foot profile. Oak is limited in distribution in this zone. The five plots examined on high mountain loam were classified as poor condition.

\section{Mountain Zone}

Climate is cool and subhumid; summers are fairly cool to warm, winters are cold and snowy. Summer prccipitation, combined with winter soil moisture, is sufficient for plant growth through most of the summer, especially on deep soils that occur in this zone. Average annual precipitation ranges from 17 to 21 inches. This zone lies between elevations of 6,500 and 8,000 feet.

Mountain loam.-Soils are deep (over 60 inches). Surface soil ( 0 to 10 inches) texture ranges from sandy loam to clay loam. The soil profile usually is free of coarse fragments, but occasionally $25 \%$ to $30 \%$ of the volume is made up of such material. Subsoils are loams to clay loams and may include $40 \%$ coarse fragments. Parent materials are sandstone, limestone, siltstone, and some granite. Subsoils are noncalcareous throughout and are slightly acid to mildly basic ( $\mathrm{pH} 6.8$ to 7.5 ). Their moisture-holding capacity averages 7 to 8 inches, but ranges from 6 to 9 inches in a 6 -foot profile. More data were taken on this site than on any other. Four range condition classes were studied: excellent (15 plots), good (22 plots), fair (22 plots), and poor (15 plots).

Mountain shallow loam.-Soils are similar to mountain loam, but are shallow (10 to 20 inches) over bedrock. The soil profile may contain up to $25 \%$ coarse fragments by volume. Moisture-holding capacity is only 2 to 2.5 inches, but plants get some additional moisture from cracks in the bedrock. Five plots in poor condition were studied on this site.

Mountain stony loam.-Soils resemble those of mountain loam, but are gravelly, stony, or cobbly and contain over $50 \%$ coarse fragments by volume. Parent materials are sandstone, shale, limestone, quartzite, schist, gneiss, and various igneous rocks. Moisture-holding capacity averages 3.5 to 4 inches, and has a range of 3 to 5 inches in a 6 -foot profile. Data were taken from three different range-condition classes: good (10 plots), fair (15 plots), and poor (15 plots).

\section{Upland Zone}

This zone, at 5,500- to 7,000-foot elevation, has cold, snowy winters and hot, dry summers. Average annual precipitation is 12 to 16 inches, but samples were taken in areas where precipitation averaged 14 to 16 inches. Upland loam soils are deep (24 to 60 inches). Parent material is loamy alluvium from mixed sedimentary and igneous rocks, but on most sample areas parent material was primarily sandstone and limestone. Surface soils range from loams to clay loams, with varying amounts of coarse fragments-usually less than $40 \%$ by volume. Subsoils (10 to 40 inches) are mostly loams, but range from gravelly fine loams and clays to cobbly sandy clay loams. Soil reaction is mildly alkaline in the surface and moderately alkaline in the substratum (pH 7.2 to 8.3). Although mostly noncalcareous in the surface, these soils are strongly calcareous in the substratum. Coarse fragments may occupy $35 \%$ of the soil profile, but generally occur in much smaller amounts. Moisture-holding capacity of upland loam soils averages 6 to 7 inches, but ranges from 5 to 9 inches in a 6 -foot profile. Two rangecondition classes, fair ( 10 plots) and poor ( 5 plots), were sampled.

\section{Results}

In preliminary tests, several variables were evaluated for their reliability in foliage production estimates. Evaluated, singly and in combination, were: foliage width; foliage length; foliage height; foliage area; foliage volume; tree height; stem diameter; number of tree stems; and basal area. Of these, foliage area, foliage volume, basal area, and the logarithms of these variables provided the most valid data for production predictions. Variance accounted for by the different variables is given in Table 1 .

On most sites, foliage area was associated more closely with foliage production than either foliage volume or basal area. A multiple regression of foliage area and basal area provided the best prediction equation. Over $75 \%$ of the variance on most sites was accounted for using these two variables. Logarithmic values did not improve the prediction equations significantly, but-since they force the curves through zero-they fit low yield data better than linear equations.

Range site and range condition affect foliage yields, but apparently range site has the greater influence. On most sites, samples of 40 clumps or segments of clones provided cstimates of oak yicld 
Table 1. Foliage yield variance accounted for $\left(\mathrm{r}^{2}\right)$ by foliage and tree measurements of oak.

\begin{tabular}{|c|c|c|c|c|c|c|c|c|c|c|}
\hline \multirow[b]{2}{*}{$\begin{array}{l}\text { Site and range } \\
\text { condition }\end{array}$} & \multicolumn{5}{|c|}{ Yield } & \multicolumn{5}{|c|}{ Log of yield } \\
\hline & $\begin{array}{c}\text { Foliage } \\
\text { area }\end{array}$ & $\begin{array}{r}\text { Foliage } \\
\text { volume }\end{array}$ & $\begin{array}{l}\text { Basal } \\
\text { area }\end{array}$ & $\begin{array}{l}\text { area } \\
\text { and } \\
\text { basal } \\
\text { area }\end{array}$ & $\begin{array}{l}\text { volume } \\
\text { and } \\
\text { basal } \\
\text { area }\end{array}$ & $\begin{array}{c}\text { Foliage } \\
\text { area }\end{array}$ & $\begin{array}{r}\text { Foliage } \\
\text { volume } \\
\end{array}$ & $\begin{array}{l}\text { Basal } \\
\text { area }\end{array}$ & $\begin{array}{l}\text { Foliage } \\
\text { area } \\
\text { and } \\
\text { basal } \\
\text { area }\end{array}$ & $\begin{array}{l}\text { volume } \\
\text { and } \\
\text { basal } \\
\text { area }\end{array}$ \\
\hline \multicolumn{11}{|l|}{ High mountain loam } \\
\hline $\begin{array}{l}\text { Excellent } \\
\text { Good } \\
\text { Fair } \\
\text { Poor } \\
\text { All }\end{array}$ & $\begin{array}{r}-- \\
-- \\
0 . \\
0.50 \\
.50\end{array}$ & $\begin{array}{r}-- \\
-- \\
-- \\
0.74 \\
.74\end{array}$ & $\begin{array}{r}-- \\
-- \\
-- \\
0.88 \\
.88\end{array}$ & $\begin{array}{r}-- \\
-- \\
-- \\
0.93 \\
.93\end{array}$ & $\begin{array}{r}-- \\
-- \\
-- \\
0.92 \\
.92\end{array}$ & $\begin{array}{r}-- \\
\ldots- \\
-- \\
0.78 \\
.78\end{array}$ & $\begin{array}{r}-- \\
-- \\
-- \\
0.87 \\
.87\end{array}$ & $\begin{array}{r}-- \\
-- \\
-- \\
0.74 \\
.74\end{array}$ & $\begin{array}{r}-- \\
-- \\
0- \\
0.90 \\
.90\end{array}$ & $\begin{array}{r}-. \\
-- \\
-- \\
0.89 \\
.89\end{array}$ \\
\hline \multicolumn{11}{|l|}{ Mountain loam } \\
\hline $\begin{array}{l}\text { Excellent } \\
\text { Good } \\
\text { Fair } \\
\text { Poor } \\
\text { All }\end{array}$ & $\begin{array}{l}.78 \\
.81 \\
.76 \\
.66 \\
.67\end{array}$ & $\begin{array}{l}.70 \\
.66 \\
.50 \\
.63 \\
.56\end{array}$ & $\begin{array}{l}.61 \\
.60 \\
.27 \\
.52 \\
.52\end{array}$ & $\begin{array}{l}.86 \\
.84 \\
.77 \\
.73 \\
.72\end{array}$ & $\begin{array}{l}.84 \\
.73 \\
.55 \\
.72 \\
.67\end{array}$ & $\begin{array}{l}.86 \\
.80 \\
.70 \\
.67 \\
.79\end{array}$ & $\begin{array}{l}.86 \\
.89 \\
.81 \\
.70 \\
.86\end{array}$ & $\begin{array}{l}.66 \\
.74 \\
.43 \\
.58 \\
.64\end{array}$ & $\begin{array}{l}.87 \\
.85 \\
.75 \\
.74 \\
.84\end{array}$ & $\begin{array}{l}.86 \\
.90 \\
.81 \\
.71 \\
.86\end{array}$ \\
\hline \multicolumn{11}{|c|}{ Mountain sha1low loam } \\
\hline $\begin{array}{l}\text { Excellent } \\
\text { Good } \\
\text { Fair } \\
\text { Poor } \\
\text { A11 }\end{array}$ & $\begin{array}{l}-- \\
-- \\
-- \\
80 \\
.80\end{array}$ & $\begin{array}{l}-- \\
-- \\
-- \\
.74 \\
.74\end{array}$ & $\begin{array}{l}-- \\
-- \\
-- \\
.19 \\
.19\end{array}$ & $\begin{array}{l}-- \\
-- \\
-- \\
.80 \\
.80\end{array}$ & $\begin{array}{l}-- \\
-- \\
-- \\
.75 \\
.75\end{array}$ & $\begin{array}{l}-. \\
-- \\
-- \\
.87 \\
.87\end{array}$ & $\begin{array}{l}-- \\
-- \\
-- \\
.82 \\
.82\end{array}$ & $\begin{array}{l}-- \\
-- \\
-- \\
.65 \\
.65\end{array}$ & $\begin{array}{l}-- \\
-- \\
-- \\
.88 \\
.88\end{array}$ & $\begin{array}{l}-- \\
-- \\
-- \\
.84 \\
.84\end{array}$ \\
\hline \multicolumn{11}{|c|}{ Mountain stony loam } \\
\hline $\begin{array}{l}\text { Excellent } \\
\text { Good } \\
\text { Fair } \\
\text { Poor } \\
\text { A11 }\end{array}$ & $\begin{array}{l}-- \\
.72 \\
.57 \\
.82 \\
.76\end{array}$ & $\begin{array}{l}-- \\
.73 \\
.62 \\
.87 \\
.79\end{array}$ & $\begin{array}{l}.- \\
.53 \\
.34 \\
.45 \\
.45\end{array}$ & $\begin{array}{l}.- \\
.77 \\
.65 \\
.84 \\
.78\end{array}$ & $\begin{array}{l}-- \\
.73 \\
.64 \\
.88 \\
.79\end{array}$ & $\begin{array}{l}-. \\
.79 \\
.51 \\
.77 \\
.71\end{array}$ & $\begin{array}{l}-- \\
.78 \\
.59 \\
.81 \\
.74\end{array}$ & $\begin{array}{l}-- \\
.51 \\
.51 \\
.40 \\
.55\end{array}$ & $\begin{array}{l}-- \\
.81 \\
.67 \\
.80 \\
.78\end{array}$ & $\begin{array}{l}.- \\
.78 \\
.69 \\
.81 \\
.76\end{array}$ \\
\hline \multicolumn{11}{|l|}{ Upland loam } \\
\hline $\begin{array}{l}\text { Excellent } \\
\text { Good } \\
\text { Fair } \\
\text { Poor } \\
\text { All }\end{array}$ & $\begin{array}{l}-- \\
-- \\
.90 \\
.82 \\
.81\end{array}$ & $\begin{array}{l}-- \\
-- \\
.61 \\
.74 \\
.62\end{array}$ & $\begin{array}{l}-- \\
-- \\
.88 \\
.68 \\
.73\end{array}$ & $\begin{array}{l}-- \\
-- \\
.93 \\
.87 \\
.85\end{array}$ & $\begin{array}{l}-. \\
-- \\
.89 \\
.80 \\
.77\end{array}$ & $\begin{array}{l}-- \\
-- \\
.88 \\
.90 \\
.78\end{array}$ & $\begin{array}{l}-- \\
-- \\
.84 \\
.88 \\
.78\end{array}$ & $\begin{array}{l}-- \\
-- \\
.74 \\
.73 \\
.72\end{array}$ & $\begin{array}{l}-- \\
-- \\
.92 \\
.92 \\
.84\end{array}$ & $\begin{array}{l}-- \\
-- \\
.86 \\
.90 \\
.82\end{array}$ \\
\hline Total all trees & .59 & .44 & .47 & .64 & .56 & .76 & .80 & .60 & .81 & .81 \\
\hline
\end{tabular}

Table 2. Regression equations for predicting yields of oakbrush foliage.

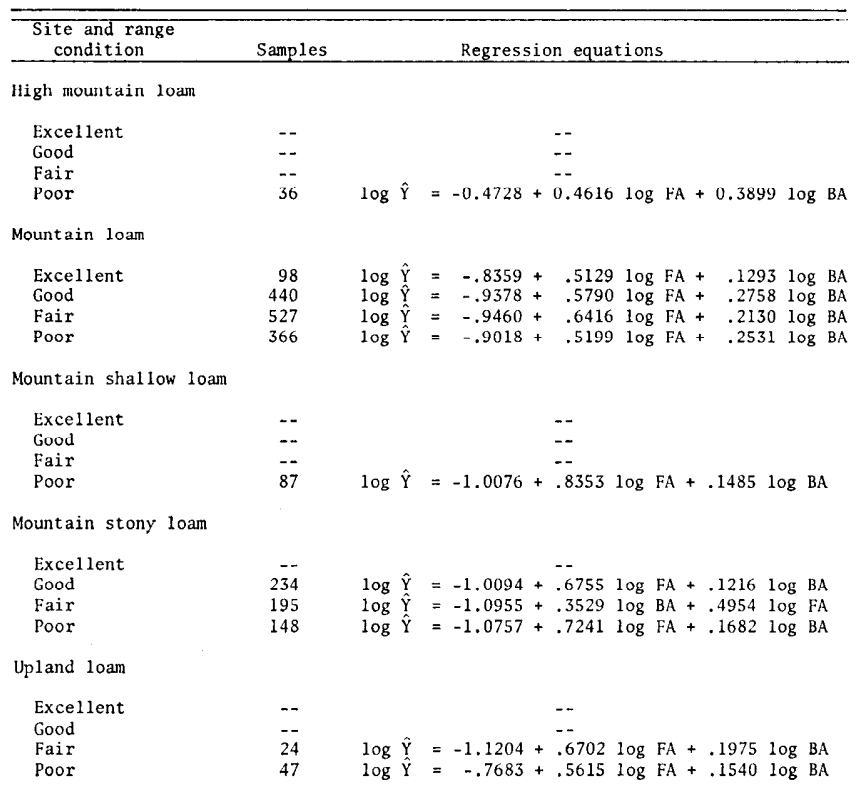

within approximately $15 \%$ of the mean ( $\mathrm{P} .05$ ). Best precision was obtained on areas where oakbrush size varied least.

Foliage yield was associated more closely with foliage area than with basal area, except on poorcondition range on high mountain loam. Oak on high mountain loam was a fairly dense stand of large trees. Equations for estimating foliage production on oak are given in Table 2.

Yields of oakbrush foliagc per square foot of foliage cover were two to three times greater on poor-condition range on high mountain loam than on poor-condition range on upland loam (Tables 3 and 4). Lowest yields per unit of cover and basal area were found on cxccllent-condition range on mountain loam (Table 5).

In several study locations on high mountain loam, mountain shallow loam, and upland loam range sites in poor condition, oak constituted over $90 \%$ of the total plant composition. Yields of Gambel oak on these sites (Table 6) indicate that oak not only persists, but probably increases as 
Table 3. Production (lb, air dry) of oak foliage on poorcondition range on high mountain loam by foliage area $\left(\mathrm{ft}^{2}\right)$ and basal area $\left(\right.$ inch $\left.^{2}\right)$.

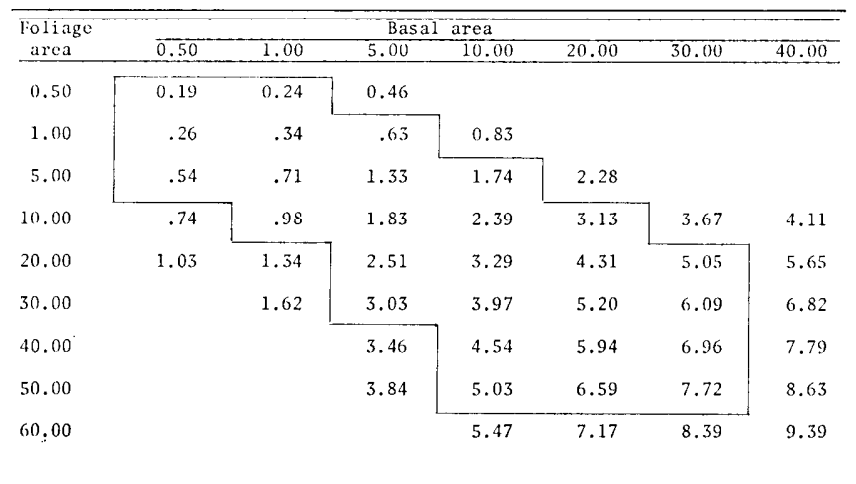

ranges deteriorate. On mountain stony loam, oakbrush yields on fair- and poor-condition range were much lower than on good-condition range. Apparently, other plants, such as big sagebrush (Artemisia tridentata) and cheatgrass (Bromus tectorum), increased or invaded areas to replace oakbrush and depleted palatable grasses and forbs.

\section{Discussion}

Oakbrush yields and cover were greatest on poorcondition range, except on the mountain stony loam site. Yields on poor-condition range were almost equal for mountain loam, mountain shallow loam, and upland loam, although foliage cover ranged from $48 \%$ to $70 \%$. Yields per square foot of foliage cover were $0.05,0.08$, and $0.07 \mathrm{lb}$., respectively (Table 6). Oak yields on poor-condition high mountain loam were double those on any other site. Heavier stands and higher yields of oakbrush apparently develop on poor-condition range following loss of palatable herbaceous vegetation.

Table 4. Production (lb, air dry) of oak foliage on poorcondition range on upland loam by foliage area $\left(\mathrm{ft}^{2}\right)$ and basal area $\left(\right.$ inch $\left.^{2}\right)$.

\begin{tabular}{|c|c|c|c|c|c|c|c|}
\hline Foliage & \multicolumn{7}{|c|}{ Basal area } \\
\hline area & 0.50 & 1.00 & 5.00 & 10.00 & 20.00 & 30.00 & 40.00 \\
\hline 0.50 & 0.10 & 0.12 & 0.15 & 0.16 & & & \\
\hline 1.00 & .15 & .17 & .22 & .24 & 0.27 & & \\
\hline 5.00 & .38 & .42 & .54 & .60 & .67 & & \\
\hline 10.00 & .56 & .62 & .80 & .89 & .99 & & \\
\hline 20.00 & & .92 & 1.18 & 1.31 & 1.45 & 1.55 & \\
\hline 30.00 & & & 1.48 & 1.64 & 1.83 & 1.94 & 2.03 \\
\hline 40.00 & & & & 1.93 & 2.15 & 2.28 & 2.39 \\
\hline 50.00 & & & & 2.19 & 2.43 & 2.59 & 2.71 \\
\hline 60.00 & & & & 2.42 & 2.70 & 2.87 & 3.00 \\
\hline
\end{tabular}

Table 5. Production (lb, air dry) of oak foliage on excellent-condition range on mountain loam by foliage area $\left(\mathrm{ft}^{2}\right)$ and basal area $\left(\right.$ inch $\left.^{2}\right)$.

\begin{tabular}{|c|c|c|c|c|c|c|c|c|}
\hline Foliage & & & & Basal & & & & \\
\hline area & 0.50 & 1.00 & 5.00 & 10.00 & 20.00 & 30.00 & 40.00 & 50.00 \\
\hline 0.50 & 0.09 & 0.10 & 0.13 & 0.14 & & & & \\
\hline 1.00 & .13 & .15 & .18 & .20 & 0.22 & & & \\
\hline 5.00 & .30 & .33 & .41 & .45 & .50 & 0.52 & & \\
\hline 10.00 & .43 & .48 & .58 & .64 & .70 & .74 & 0.77 & \\
\hline 20.00 & & .68 & .84 & .91 & 1.00 & 1.05 & 1.09 & 1.13 \\
\hline 30.00 & & & 1.03 & 1.14 & 1.23 & 1.30 & 1.35 & 1.38 \\
\hline 40.00 & & & 1.19 & 1.30 & 1.43 & 1.50 & 1.56 & 1.61 \\
\hline 50.00 & & & & 1.46 & 1.60 & 1.68 & 1.75 & 1.80 \\
\hline 60.00 & & & & 1.61 & 1.76 & 1.85 & 1.92 & 1.98 \\
\hline
\end{tabular}

$\log \hat{Y}=-0.83587+0.51294 \log \mathrm{FA}+0.12925 \log \mathrm{BA}\left(\mathrm{r}^{2}=0.87\right)$

Yearly variations in foliage yield were not evaluated. Yield data should be obtained for all rangecondition classes over a period of several years to evaluate yearly fluctuations in production. Prediction equations derived from this study will be checked in the field to determine their reliability.

Foliage production estimates probably can be improved by grouping oak cover into foliage classes based on denseness or compactness of foliage-as was done with juniper foliage (Mason and Hutchings, 1967)-and by sampling oak foliage by clones instcad of by belt transects, which cut across clonal areas.

Table 6. Yield and cover of current annual growth of Gambel oak on various range sites and range-condition classes.

\begin{tabular}{ccccc}
\hline \multirow{2}{*}{$\begin{array}{c}\text { Site and range } \\
\text { condition }\end{array}$} & Yield & Cover & Cover & Yield \\
\cline { 2 - 6 } & $\begin{array}{l}\text { Lb/acre, } \\
\text { air dry }\end{array}$ & $\mathrm{Ft}^{2} / \mathrm{acre}$ & Percent & $\mathrm{Lb} / \mathrm{ft}^{2}$ \\
\hline
\end{tabular}

High mountain loam

Excellent
Good
Fair
Poor

$\begin{array}{cccc} & & & \\ -- & -- & -- & -- \\ -- & -- & -- & -- \\ -\overline{3}, 186 & 17,300 & -- & -- \\ & & 40 & 0.18\end{array}$

Mountain loam

Excellent
Good
Fair
Poor

Poor

Mountain shallow loam

Excellent

$$
\text { Good }
$$

Fair

Mountain stony loam

Excellent

Good

Fair

Poor

Up1and loam

Excellent

Gair

Fair
Poor 


\section{Summary}

Reliable estimates of oakbrush foliage and twig yield can be made from measurements of foliage cover and basal stem area. Based on samples from 30 to 50 oakbrush areas, predictions can bc made that are within $10 \%$ of the actual average yield. Logarithmic equations provided the best correlations for this study. Separate equations are needed for different sites and range-condition classes. Al- though data were gathered during three field seasons, yearly differences in yield were not evaluated. Prediction equations and yield tables developed from this study should be checked for application in the field.

\section{Literature Cited}

Mason, Lamar R., and Selar S. Hutchings. 1967. Estimating foliage yields on Utah juniper from measurements of crown diameter. J. Range Manage. 20:161-166. 